Хрестоматия по психологии :[учеб. пособие для студ. пед. ин-тов] / [под ред. проф. А. В. Петровского]. - М. : Просвещение, 1997. - С. 400-424. 3. Лов'янова I. В. Формування інтелектуальних умінь старшокласників у процесі вивчення предметів природничого циклу: автореф. дис. на здобуття наук. ступеня канд. пед. наук: спец. 13.00.09 «Теорія навчання» / I. В. Лов'янова. - К., 2006. - 20 с. 4. Монастирна Г. В. Формування професійної компетентності майбутніх учителів інформатики засобами інформаційно-педагогічного моделювання: автореф. дис. на здобуття наук. ступеня канд. пед. наук: 13.00.04 «Теорія і методика професійної освіти» / Г. В. Монастирна; Луганський нац. ун-т ім. Тараса Шевченка. - Луганськ, 2009. - 20 с. 5. Нічуговська Л. І. Науково-методичні основи математичної освіти студентів економічних спеціальностей вищих навчальних закладів: автореф. дис. на здобуття наук. ступеня д-ра пед. наук: спец. 13.00.04 «Теорія і методика професійної освіти» / Л. І. Нічуговська. - К., 2005. - 36 с. 6. Новик И. Б. О моделировании сложных систем / И. Б. Новик. - М. : Мысль, 1965. - 335 с. 7. Савченко Г. О. Формування готовності майбутніх фахівців банківської справи до аналітичної діяльності засобами моделювання: автореф. дис. на здобуття наук. ступеня канд. пед. наук: спец. 13.00.04 «Теорія і методика професійної освіти» / Г. О. Савченко. - Одеса, 1993. - 18 с.

УДК 377.35

Людмила Цвіркун

\title{
ПРОЕКТНО-КОНСТРУКТОРСБКА КОМПЕТЕНТНІСТЬ ЯК СКЛАДНИК ПРОФЕСІЙНОЇ ГОТОВНОСТІ МАЙБУТНЬОГО ІНЖЕНЕРА
}

Цвіркун Л. О. Проектно-конструкторська компетентність як складник професійної готовності майбутнього інженера.

У статті розглянуто наукові поняття «професійна компетенція», «професійна компетентність» та «проектно-конструкторська компетентність майбутнього інженера», уточнено сутність використовуваних понять в аспекті компетентнісного підходу, конкретизовано терміни та надано авторське визначення проектноконструкторської компетентності як невід'ємного складника професійної готовності майбутнього інженера.

Ключові слова:інженер, компетентнісний підхід, професійна компетенція, професійна компетентність, проектно-конструкторська компетентність майбутнього інженера, графічні дисципліни.

Цвиркун Л. А. Проектно-конструкторская компетентность как составляющая профессиональной готовности будущего инженера.

В статье рассмотрены научные понятия «профессиональная компетенция», «профессиональная компетентность» и «проектно-конструкторская компетентность будущего инженера», уточнена сущность использованных понятий в аспекте компетентностного подхода, конкретизированы термины, дается авторское определение проектно-конструкторской компетентности как неотъемлемой составляющей профессиональной готовности будущего инженера.

Ключевые слова: инженер, компетентностный подход, профессиональная компетенция, профессиональная компетентность, проектно-конструкторская компетентность будущего инженера, графические дисциплины.

Tsvirkun L. O. Design and engineering expertise are the training of future engineers.

The article describes the scientific concept of «expertise», "professional competence» and «design and engineering expertise of the future engineer» refine the concepts used in the aspect of the competency approach concretized terms and given the author's definition of 
design competence as an integral part of professional readiness of the future engineer.

Keywords: engineer, competence approach, expertise, professional competence, design and engineering expertise of the future engineer, graphic discipline.

У зв'язку з модернізацією та вдосконаленням національної системи вищої освіти України в контексті європейської інтеграції постає необхідною підготовка професійно компетентного фахівця, здатного розв'язувати організаційно-виробничі, науководослідні, інженерно-графічні завдання, виконувати проектно-конструкторські роботи, застосовуючи інформаційні технології та графічні системи.

На необхідності розвитку професійної компетентності майбутнього фахівця наголошено в Національній доктрині розвитку освіти, у якій приділено увагу заходам щодо підвищення якості освіти в Україні та створення необхідних умов для розвитку, самовдосконалення і самореалізації у професійній діяльності [9]. Про це свідчить Державна національна програма «Освіта. Україна XXI століття», у якій головним завданням вищої освіти визначено спрямованість на забезпечення фундаментальної наукової і практичної підготовки інженерів. Окрім того, формування інтелектуального потенціалу особистості як найвищої цінності суспільства [4]. Відповідно, підготовка студентів у ВНЗ потребує нової спрямованості освітнього процесу, де одним із пріоритетних орієнтирів $\epsilon$ формування професійної компетентності майбутнього фахівця.

Розв'язання окресленої проблеми тісно пов'язане із запровадженням компетентнісного підходу як перспективного напряму розвитку сучасної освіти. У цьому процесі головними $\epsilon$ не окремі знання, уміння та навички, а здатність і готовність до ефективної та продуктивної діяльності в різних соціально значущих ситуаціях [8, с. 16]. Отже, студент повинен опанувати такий набір компетенцій та компетентностей, який дозволить йому успішно здійснювати професійну діяльність, зокрема проектно-конструкторську.

Грунтовно підходить до цього питання 3. Бакум, яка вважає, що компетентнісний підхід $€$ орієнтиром, який спрямовує дії викладача на розвиток компетентної особистості. Автор зазначає, що успішність розвитку залежить від багатьох чинників, серед яких найбільш значущі - підвищення рівня мотивації студента; підвищення частки індивідуальної самоосвіти, уваги до способів роботи 3 інформацією, форм і методів навчання тощо [1]. Відповідно, головним завданням компетентнісного підходу $\epsilon$ така організація навчального процесу, яка надає змогу забезпечити спроможність випускника відповідати новим запитам ринку. Усе це спричиняє висунення нових вимог до підготовки інженерів, де стратегічним завданням $\epsilon$ готовність до професійної діяльності.

Mema cmammi- уточнити сутність поняття «проектно-конструкторська компетентність майбутнього інженера» та розкрити вплив графічних дисциплін на іiі формування.

Слід зауважити, що багатоаспектність понять «професійна компетенція», «професійна компетентність» i «проектно-конструкторська компетентність майбутнього інженера», їх актуальність спричинили появу значної кількості наукових публікацій та досліджень, які можна охарактеризувати різноманітністю авторських підходів та концепцій.

У контексті проблеми, що 3'ясовується, необхідно уточнити сутність використовуваних понять у психолого-педагогічній літературі. На основі порівняння й узагальнення отриманої інформації надати власне визначення проектноконструкторської компетентності й окреслити іiі місце уформуванні професійної 
готовності майбутнього інженера.

Науковці, які досліджують різні аспекти професійної компетентності, зокрема інженера (В. Городецький, А. Дорофєєва, Е. Зеєр, А. Маркова, О. Мусієнко та ін.), розглядають іï як сукупність професійних знань та умінь; здібність до актуального виконання діяльності; способи виконання виробничих завдань. Так, А. Маркова розглядає професійну компетентність як самостійне i відповідальне виконання професійних обов'язків. Автор виокремлює такі іiі складники: спеціальна компетентність (володіння професійними знаннями, здатність проектувати свій подальший професійний розвиток); соціальна компетентність (володіння спільною професійною діяльністю, співпрацею); особистісна компетентність (володіння прийомами особистісного самовираження i саморозвитку); індивідуальна компетентність (готовність до професійного зростання, уміння організувати раціонально свою працю) [6, с. 34]. Окреслені складники професійної компетентності вагомі і для майбутнього інженера.

Слід зауважити, що для успішної проектно-конструкторської діяльності фахівцю необхідно володіти певним набором компетенцій. Так, В. Городецький уважає, що структура компетенцій інженера реалізується в чотирьох компонентах кваліфікаційних умінь: проектувальні- планування професійної діяльності; організаторські - реалізація інженерного задуму; конструкторські - виконання ескізів, креслень; гностичні - читання ескізів, креслень, схем тощо [3, с. 6]. Отже, професійна компетентність інженера передбачає успішне розв'язування інженерних завдань, для цього необхідно мати високий рівень мотивації до професійної діяльності та відповідні знання й уміння.

Щодо інженерної освіти, то О. Мусієнко уточнює, що професійна компетентність інженера - це інтегративна характеристика спеціаліста, здатного кваліфіковано виконувати певні функції у всіх видах професійної діяльності, що регламентуються кваліфікаційними вимогами спеціальності $[7$, с. 36]. Відповідно до цього можна стверджувати, що професійна освіченість $є$ вагомим складником усього технологічного процесу та передбачає здатність розв'язувати виробничі завдання. Слід акцентувати увагу й на тому, що студент у майбутньому стане інженером-професіоналом лише в тому випадку, якщо вийти 3 простору знань у простір діяльності, для цього йому необхідно поєднати отримані знання у ВНЗ та досвід практичної діяльності.

Доцільно згадати позицію С. Татьяненко, яка у своїй праці розробила структурну схему поняття «професійна компетентність майбутнього інженера», що поєднує професійну діяльність, що передбачає науково-дослідну, проектно-конструкторську, організаційно-управлінську, виробничо-технологічну та експлуатаційну роботу та професійні якості особистості [10, с. 12]. Майбутній інженер повинен не тільки мати професійні знання, а також уміти діяти серед людей, що знаходяться в колективі та мають відношення до технологічного процесу.

Сучасний інженер, окрім грунтовної теоретичної підготовки за фахом, уміння розв'язувати професійні завдання за допомогою інтелектуальної діяльності та розумових дій (аналіз, порівняння, прогнозування і як наслідок синтез) повинен бути відповідальною, самостійною, цілеспрямованою особистістю, яка здатна співпрацювати в колективі та знаходити спільну мову з людьми, навчатися упродовж усього життя задля підвищення своєї професійної компетентності. На цьому наголошують науковці (О. Коваленко, В. Онищенко, В. Сидоренко та ін.), які у своїх працях зазначають, що інженеру необхідно мати широкий науковий світогляд та сформовані знання під час вивчення загальноінженерних та спеціальних дисциплін у 
ВН3, що є фундаментом для успішної професійної діяльності.

У руслі сучасного виробництва спостерігається стрімкий розвиток технологій автоматизованого проектування, що сприяє здійсненню комп'ютеризації багатьох процесів. Це потребує від інженера багатофункціональності та варіативності рішень у процесі розв'язуванні виробничих завдань. Відповідно, інженер повинен володіти комплексом знань, які грунтуються на науково-теоретичній, інженерно-графічній та інформаційно-технологічній базі та бути готовим до різноманітних форм самоосвіти протягом життя, що, у свою чергу, вимагає нового підходу до формування професійної компетентності інженера.

Останнім часом у педагогічній науці здійснюються пошуки шляхів для розв'язання окресленої проблеми. Одне з чільних місць у процесі підготовки інженерів посідає проектно-конструкторська компетентність, формування якої спрямовано на підвищення готовності майбутнього інженера до професійної діяльності.

Науковці, які досліджують проблему проектно-конструкторської компетентності (Л. Добровська, С. Вехтер, О. Ерцкіна та ін.), уважають, що це інтегративна, сформована характеристика здатності і готовності випускника, що виявляється у проектуванні на основі володіння спеціальними знаннями, уміннями та навичками проектноконструкторської діяльності; здатність розв'язувати професійні проблеми; готовність передбачати результати своєї діяльності. Проектно-конструкторська діяльність пов'язана з використанням сучасних систем автоматизованого проектування.

Так, Є. Вехтер уточнює, що вагомою ознакою проектно-конструкторської компетентності $\epsilon$ готовність випускника використовувати сучасні інформаційні технології та засоби проектування, які швидко змінюються 3 невпинним розвитком науково-технічного прогресу, та його здатність до інженерної творчості та самоосвіти протягом усього життя [2, с. 10].

Виходячи $з$ аналізу наукових досліджень, слід зауважити, що основною ознакою проектно-конструкторської компетентності $€$ багатогранність, яка потребує інтелектуальної діяльності, розвитку просторової пам'яті, уяви, логічного та технічного мислення. На нашу думку, одне із чільних місць у формуванні розумових процесів посідають графічні дисципліни, завдяки яким студенти навчаються правильно читати креслення та схеми, виконувати інженерно-графічні завдання, проектно-конструкторські роботи, застосовуючи графічні програми. На цьому наголошують і науковці (В. Кальницький, Т. Панюшкіна, Б. Тарасов), зосереджуючи увагу на важливості графічних дисциплін у навчальному процесі ВНЗ, тому що під час їх вивчення у студентів відбувається розвиток професійних якостей, які впливають на майбутню професійну діяльність.

Отже, становлення проектно-конструкторської компетентності майбутнього інженера пов'язане з вивченням графічних дисциплін, які є фундаментом професійної діяльності. Відповідно до цього науковці окреслюють основні завдання, які покладено на складники циклу математичної та природничо-наукової підготовки - графічні дисципліни: професійні- досвід застосування графічних знань у виробничій діяльності та науці; інформаційні - можливість застосування інформаційнокомунікаційних технологій у професійній діяльності; проектно-конструкторськіпроектування, конструювання та моделювання; соціальні - виховання та адаптація майбутнього фахівця за допомогою уявлень про графічну культуру [5]. Досвід показує, що під час вивчення графічних дисциплін у студентів відбувається розвиток здатності до аналізу та синтезу графічних завдань, уміння проектувати тривимірні моделі деталей, грамотно реалізовувати лаконічну графічну мову, застосовуючи 
сучасні комп'ютерні програми.

Одним із напрямів професійної підготовки сучасного інженера $є$ графічна підготовка, основне завдання якої полягає у формуванні проектно-конструкторської компетентності. Відповідно, інженер повинен знати технологію і техніку проектноконструкторської роботи, брати участь у проектувальній та винахідницькій діяльності, керуватися не лише установленим практичним, а схилятися до новаторськогопідходу в інженерній діяльності та володіти різноманітними формами самоосвіти.

3 огляду на вищезазначене можна вважати, що проектно-конструкторська компетентність відіграє все більш важливу роль у житті освіченого інженера, невід'ємно пов'язана 3 розвитком багатьох компонентів, основне завдання яких полягає у всебічному розвитку студента як особистості, який прагне подальшого збагачення та зростання свого професійного потенціалу.

Наведені визначення та концепції «проектно-конструкторської компетентності майбутнього інженера» в освітньому процесі стали орієнтиром для створення власного визначення досліджуваного поняття.

Відтак, проектно-конструкторську компетентність майбутнього інженера визначаємо як характеристику готовності студента до майбутньої професійної діяльності, що виявляється у поетапному накопичуванні нормативно визначених графічних знань, умінь та навичок у процесі вивчення графічних дисциплін, передбачає вільне володіння інформаційними технологіями та графічними системами, а також у здатності до подальшого збагачення та зростання свого освітнього потенціалу.

Нині майбутній інженер повинен мати сформовану проектно-конструкторську компетентність, саморозвиватися та вдосконалюватися як творча особистість у процесі професійної діяльності для подальшого розвитку своєї професійної компетентності.

1. Бакум 3. П. Компетентнісний підхід до мовленнєвого розвитку старшокласників в умовах профільного навчання української мови [Електронний pecypc] / 3. П. Бакум. - Режим доступу : http:// http://www.allbest.ru/. 2. Вехтер Е. В. Развитие проектно-конструкторских компетенций бакалавров технического профиля: автореф. дис. на соискание учен. степени канд. пед. наук: спец. 13.00 .08 «Теория и методика профессионального образования» / Е. В. Вехтер. - Тобольск, 2012. - 25 с. 3. Городецкий В. В. Формирование профессиональных компетенций как психологопедагогическая проблема / $\mathrm{B.} \mathrm{В.} \mathrm{Городецкий} \mathrm{[Электронный} \mathrm{ресурс]} \mathrm{//} \mathrm{Сборник}$ научных трудов СевКавГТУ. Серия «Гуманитарные науки». - 2008. - № 6. - Режим доступу: http://science.ncstu.ru/ articles/hs/2008_06. 4. Державна національна програма «Освіта. Україна XXI століття»: Постанова, Програма, Заходи від 3 листопада 1993 р. N 896 / Кабінет міністрів України. - Режим доступу: zakon4.rada.gov.ua/laws/show/89693-\%D0\%BF. 5. Кальницкий В. Л. Введение в машиную графику: [учебное пособие] / В. Кальницкий, Б. Тарасов. - Львов, 1986. - 94 с. 6. Маркова А. К. Психология профессионализма / А. К. Маркова. - М. : Международный гуманитарный фонд «Знание», 1996. - 308 с. 7. Мусиенко О.А. Развитие профессиональной компетентности студентов строительных специальностей в процессе изучения графических дисциплин: дис. канд. пед. наук: спец. 13.00.02/ Мусиенко Ольга Алексеевна. - М., 2007. - 203 с. 8. Овчарук О. В. Компетентності як ключ до оновлення змісту освіти / О. В. Овчарук // Стратегія реформування освіти в Україні. К., 2003. - С. 13-41. 9. Про Національну стратегію розвитку освіти в Україні на період до 2021 року: Указ, Стратегія від 25 червня 2013 року №344/2013/ Президент України. - Режим доступу: http://zakon2.rada.gov.ua/laws/show/344/2013. 10. Татьяненко С. А. Формирование профессиональной компетентности будущего 
инженера в процессе обучения математике в техническом вузе: автореф. дис. на соискание учен. степени канд. пед. наук: спец. 13.00.02 «Теория и методика обучения и воспитания» / С. А. Татьяненко. - Тобольск, 2003. - 24 с. 